九州大学学術情報リポジトリ

Kyushu University Institutional Repository

\title{
Effects of Moisture Content on Soil Strength around Kampung Lohan, Ranau, Sabah
}

\section{Karthigeyan Al. Ramanathan}

Faculty of Civil Engineering, Universiti Teknologi Malaysia

Mohamed Ali Yusof Mohd. Hus in

Faculty of Science and Natural Resources, Universiti Malaysia Sabah

Rini Asnida Binti Abdullah

Faculty of Civil Engineering, Universiti Teknologi Malaysia

Afikah Binti Rahim

Faculty of Civil Engineering, Universiti Teknologi Malaysia

https://doi.org/10.5109/4102493

出版情報: Proceedings of International Exchange and Innovation Conference on Engineering \& Sciences (IEICES). 6, pp. 225-230, 2020-10-22. Interdisciplinary Graduate School of Engineering Sciences, Kyushu University バージョン：

権利関係 : 


\title{
Effects of Moisture Content on Soil Strength around Kampung Lohan, Ranau, Sabah
}

\author{
Karthigeyan Al.Ramanathan ${ }^{1, *}$, Mohamed Ali Yusof Mohd.Husin ${ }^{2}$, Rini Asnida Binti Abdullah ${ }^{1}$, Afikah Binti Rahim ${ }^{1}$, \\ Norafida Binti Jusoh ${ }^{1}$ \\ ${ }^{1}$ Faculty of Civil Engineering, Universiti Teknologi Malaysia, 81310 Johor Bahru, Johor, Malaysia \\ 2 Faculty of Science and Natural Resources, Universiti Malaysia Sabah, 88400 Kota Kinabalu, Sabah, Malaysia \\ *Corresponding author email: karthigeyan-1994@graduate.utm.my
}

\begin{abstract}
Ranau landslides mostly occur due to moisture content and soil properties. In this study, the effect of moisture content on soil strength was analyzed using Unconfined Compression Test. Five samples were taken around Kampung Lohan which two are Crocker Formation soil samples (K1 and K3) and three were ultrabasic soil samples (K2, K4 and K5). The term 'Decrement Difference of Unconfined Compression Strength' is used to define the percentage drop of shear strength difference of the manipulated oversaturated samples to its shear strength at optimum moisture. The highest drop was $90.18 \%$ in clayey soil (K2) because it is rich in minerals that are able to absorb and adsorb water while lowest drop of $50.32 \%$ by sandy clay with silt (K1). Thus, sand rich soils of Crocker Formation have higher compression strength than ultrabasic soils with expansive clay while the moisture effect on soil is directly proportional to thecompression strength.
\end{abstract}

Keywords: Landslide; moisture content; 'Decrement Difference of Unconfined Compression Strength'

\section{INTRODUCTION}

The state of Sabah located on the Eurasian Plate has long been tectonically active, although being static due to the movement of several plates towards it [1]. For example, the Pacific Plate, Philippines Sea Plate, Indo- Australian Plate and Caroline Plate (Figure 1). These active plate movements caused a magnitude 6 earthquake on the $5^{\text {th }}$ June of 2015 which caused many landslides and ground instability to occur [2].

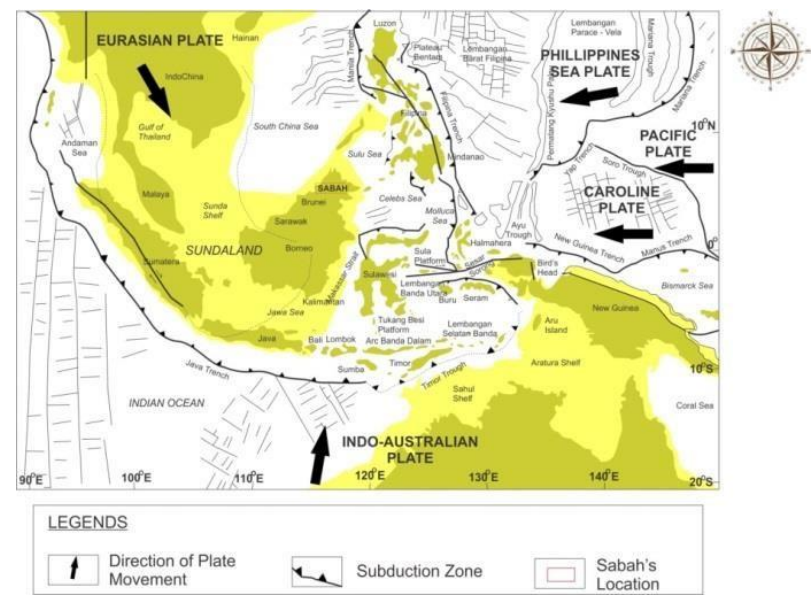

Figure 1: Plate movements near Sabah [1].

However, the primary factors that induced these landslides are the soil moisture content and its properties that quantitatively represent its shear strength values. This issue can be seconded by the fact of Ranau having an intense tropical climate which receives a fair amount of rain and shine. Recently, statistical data by the Meteorological Department of Malaysia has shown annually that about $83 \%$ having a total rainfall of more than $70 \mathrm{~mm}$ per month. According to Bujang [3], frequent intense rainfall as such in short periods of time can cause landslides or slope failures that harm the environment and public in Malaysia.

From the previous statement, this prioritizes the need to understand the differences of soil strength during optimum and oversaturated conditions (rainfall). Then, Mohd. Ali Yusof [4] introduced a simple formula namely the Shear Strength Difference and has proven its significance on soil samples from Crocker Formation in Tamparuli. Although this method has clearly been successful on Crocker Formation, the status of other origins of soil samples is yet to be clearly ascertained in Sabah.

The scope of this study only revolves around Kampung Lohan in Ranau area which comprises of two studied soil samples which are the Crocker Formation and ultrabasic origin. Thus, this paper provides some insights on the comparisons between these two origins by thoroughly understanding the effects of moisture content on soil strength that is prone to induce landslides.

\section{STUDY AREA}

The study area is located around Kampung Lohan, Ranau, Sabah, Malaysia. This area is underlain by 5 different stratigraphic rock units. For example, the igneous origins of Ultrabasic and Acid Intrusion while the sedimentary origins of Trusmadi and Crocker Formation. Besides that, there are also the Pinosouk Gravel and Quaternary Alluvium sedimentations found at the study area.

However, there were limitations in retrieving Grade 6 residual soils from each of the stratigraphy units at the study area. Hence, detailed studies on two units were carried out such as ultrabasic (K1 \& K3) and Crocker Formation (K2, K4 \& K5) soil samples. The locations of these samples are shown in Table 1 and Figure 2. 
Table 1: Summary of soil samples studied.

\begin{tabular}{|l|l|l|}
\hline Sample & Sampling Location & Parent Rock Unit \\
\hline K1 & Kg. Kilimu & Crocker Formation \\
\hline K2 & Kompleks Sukan Ran & Ultrabasic Rocks \\
\hline K3 & Kg. Napong & Crocker Formation \\
\hline K4 & Kg. Nampasan Baru & Ultrabasic Rocks \\
\hline K5 & $\begin{array}{l}\text { Kilometer 22, Jalan } \\
\text { Ranau-Sandakan }\end{array}$ & Crocker Formation \\
\hline
\end{tabular}

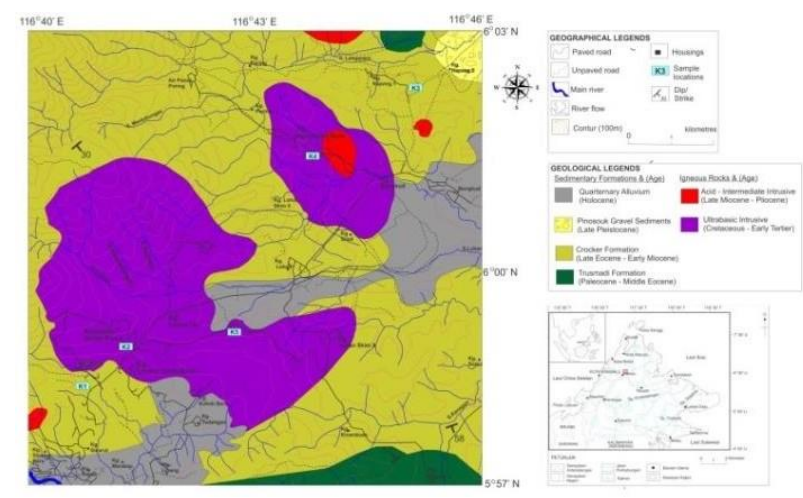

Figure 2: Map of sampling locations based on the geological background.

During the weathering process with the aid of an intense tropical climate, residual soils will e xhibit some characteristics which were inherited from its parent rock unit [5]. A thorough understanding on this matter must be acquired to further understand the physic-chemical and engineering properties of the studied soil samples. The ultrabasic rock like peridotite is majorly found in the Ranau areas. This rock unit was formed from the magma cooling that occurred on the mid-oceanic ridges during the Cretaceous period [6]. But, active tectonics has caused the uplift and deformation of this rock type causing serpentinization process to occur. According to [7], this process increases the formation of fines and dark coloured minerals like goethite during weathering process which adsorbs a massive amount of moisture which eventually reduces it soil strength (Figure $3 a$ ).

While, the Late Eocene to Early Miocene aged Crocker Formation is classified as a deep marine environmental deposit. Crocker Formation is divided to interbedded sandstones and shale unit, shale unit and thick sandstone unit [8]. Thus, a sandstone parent rock rich with lighter coloured minerals like quartz will show a greater amount of coarse grained material in the soil's particle size distribution curve(Figure 3b).
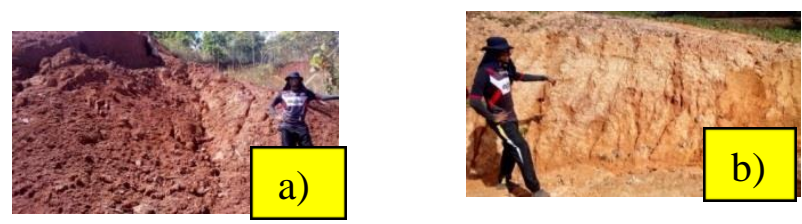

Figure 3: a) Example of ultrabasic soil sample from location K2; b) Example of soil sample from Crocker Formation (K3).

\section{MATERIALS AND METHODOLOGY}

Five soil samples were obtained from the studied area with each weighing about 20 kilograms. There were few laboratory tests carried out to identify the soil properties in terms of physic-chemical (PSD), microstructural (SEM) and engineering behaviors such as Proctor Compaction and UCT [9].

Firstly, the Particle Size Distribution (PSD) test was carried out in accordance with the British Standard, [10]. This test helped to determine the weight and range of sizes of particles like sand, silt and clay in a soil material (Head, 1982) classification.

The analysis of soil microstructures was done using the Scanning Electron Microscope (SEM) method. Each sample was dried and grinded in a small amount of weight before observing the soil microscopic features and minerals under the microscope.

Besides that, the Proctor Compaction Test was performed by following the method proposed by [10]. The uniaxial compacted soil grains with limited void space helps to identify the optimum moisture and ma ximum dry density [11]. This analysis is done under the undrained conditions with limited amount of time by steadily increasing the axial compression until failure occurs [4].

The Proctor Compaction's data, the Unconfined Compression Test (UCT) was carried out in accordance with [10]. At initial stage, UCT test was performed on each soil samples at its optimum moisture content and ma ximum dry density. Then, the soil samples are tested

with manipulated values of additional moisture content. In this study, the Crocker Formation soil samples are added with $3 \%$ of water from its optimum moisture, however the ultrabasic soil samples was tested using only a mere addition of $1 \%$. This is due to difficulty in handling the soil samples if more than $1 \%$ of water is added into a swelling soil type like the ultrabasic soil. The $3 \%$ and $1 \%$ used respectively was considered as the best values to demonstrate the main objective of this study after several trial and errors were done by using various other percentage additions (Figure 4). Furthermore, the formula used in this study is termed as Decrement Difference of Unconfined Compression Strength. It shows a decrement of soil strength due to the addition of moisture content which induces extra weakness plane in the soil material.

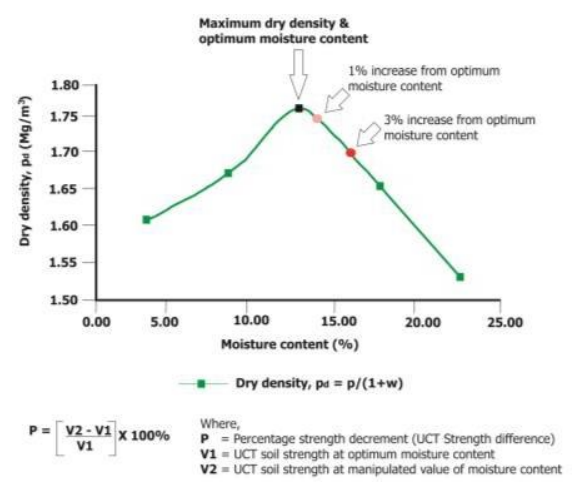

Figure 4: Illustration of the manipulated percentage of moisture content from its optimum value with the formula used in this study (modified from Mohd. Ali Yusof [4]). 


\section{RESULTS ANDDISCUSSION}

The weathering process on the parent rock unit of a slope produces residual soil layer which comprises of various particle sizes. In order to classify these particles, the particle size distribution (PSD) test needs to be done thoroughly. These classifications are for the percentage of sand, silt and clay in a specific soil sample based on [12]. The results are shown below in Table 2 andFigure 5.

Table 2: Classification of each soil samples based on Head (1982) classification in Figure 5.

\begin{tabular}{|c|c|c|c|c|c|}
\hline Sample & K1 & K2 & K3 & K4 & K5 \\
\hline \% Sand & 54.00 & 26.86 & 43.94 & 44.70 & 31.47 \\
\hline \% Silt & 20.50 & 40.58 & 29.03 & 3.04 & 43.02 \\
\hline \% Clay & 25.50 & 32.56 & 27.03 & 52.26 & 25.51 \\
\hline $\begin{array}{c}\text { Classification } \\
\text { (Head, 1982) }\end{array}$ & $\begin{array}{c}\text { Sandy } \\
\text { Clay } \\
\text { with } \\
\text { Silt }\end{array}$ & Clay & $\begin{array}{c}\text { Sandy } \\
\text { and } \\
\text { Silty } \\
\text { Clay }\end{array}$ & Clay & $\begin{array}{c}\text { Sandy } \\
\text { and } \\
\text { Silty } \\
\text { Clay }\end{array}$ \\
\hline
\end{tabular}

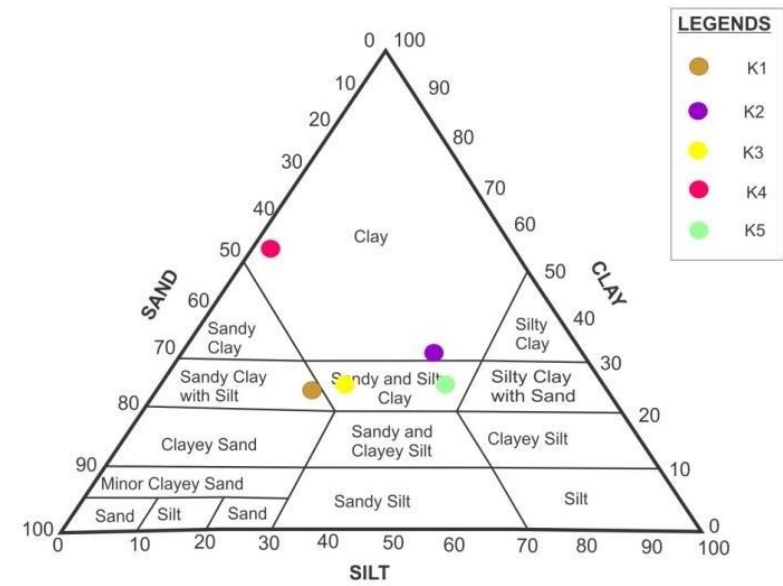

Figure 5: Triangular soil textural classification (modified from Head [12]).

From Table 2 and Figure 5, it can be concluded that the Crocker Formation soil samples (K1 \& K3) has a higher sand content compared to the ultrabasic soil samples (K2, K4 \& K5) and vice-versa for other particle contents. Ultrabasic soil samples tend to have higher clay and silt content due to parent rock unit of peridotite that contains lower amount of $\mathrm{SiO}_{2}$ content which quantitatively explains its dark coloured characteristics [13]. These fine partcles plays a very important role on the effects of moisture content on its soil strength. According to Zulfahmi [14], clay is a weak secondary mineral which forms from the weathering process of primary minerals like feldspar. These minerals tend to have a larger total surface area over volume which makes it prone to excessive moisture absorption and weakening of strong bonds between soilparticles.

By using the formula given in Figure 4, a complete UCT analysis has been done using the optimum $(\%)$ and manipulated (\%) moisture contents on each of the soil samples studied (Table3).
Table 3: UCT results of optimum and manipulated moisture contents with its soil classifications.

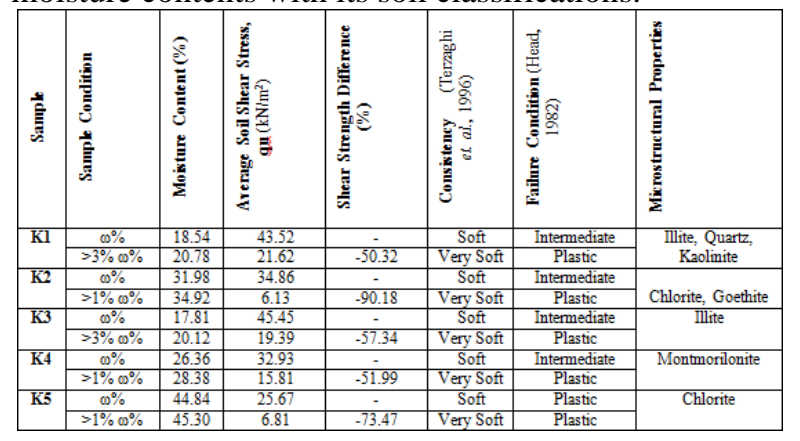

Table 3 shows that the unconfined compression strength of soil samples decreases with increasing moisture content. This trend is due to the attenuation of soil cohesive strength as shown in Figure 6. The increasing soil moisture allows for more water molecules to be adsorbed onto the clay particle surface which eventually forms a thick water layer around it [15]. The expansion of this hydrated water layer will occur till causing the increase of distance between soil particles and water molecules. In addition, this separation then weakens the pulling force or bond of particle, thus decreasing the soil cohesiveness. In this situation, the weaken bonds acts as a weakness plane with the aid of water to trigger the soil failure during load stressing. According to Alvarado [16], this soil condition is not suitable to be used as a foundation material for buildings as the soil shear stress is much higher than the soil shear strength.

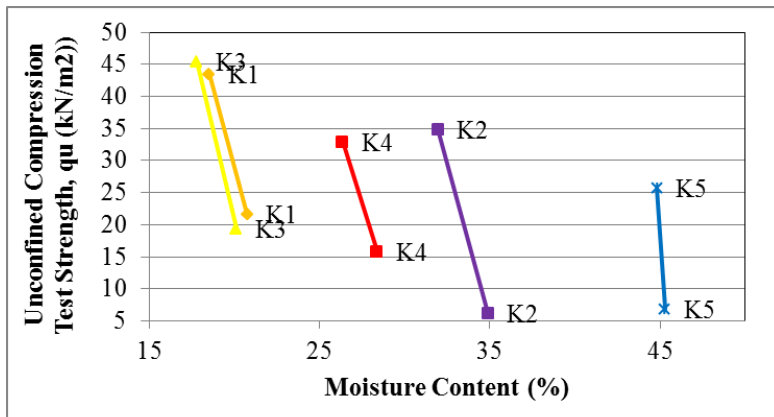

Figure 6: UCT strength of soil decreases with increasing moisture content for each samples tested.

By using the Decrement Difference of Unconfined Compression Strength formula, a simple analysis is done as shown in Figure 7. The range of soil strength decrease once the moisture content is manipulated is between $50.32 \%$ till $90.18 \%$. The sandy clay with silt soil sample from Crocker Formation (K1) scored a lowest strength decrement $(50.32 \%)$ while the highest decrement of 90.18\% was from the clayey ultrabasic soil samples (K2). Generally, finer soil particles like clays are more susceptible to failure compared to coarse grain particles. This is influenced by the clay characteristics that have the tendency to absorb and store water into their complex microstructures [17]. Hence, the microstructural analysis plays a vital role in this study to understand the soil behaviors as shown in Figure 8. 


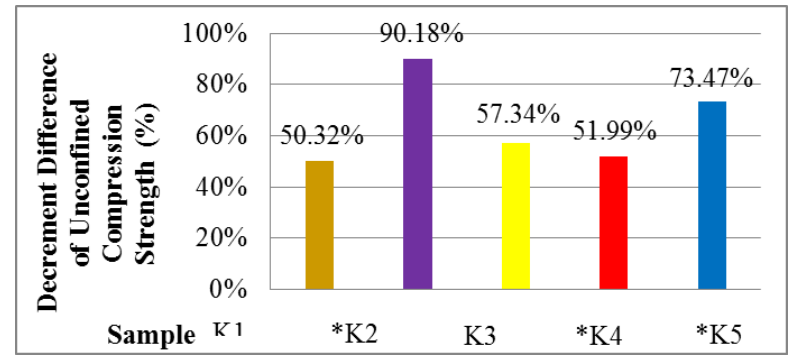

Figure 7: Decrement difference of unconfined compression strength of each soil samples.

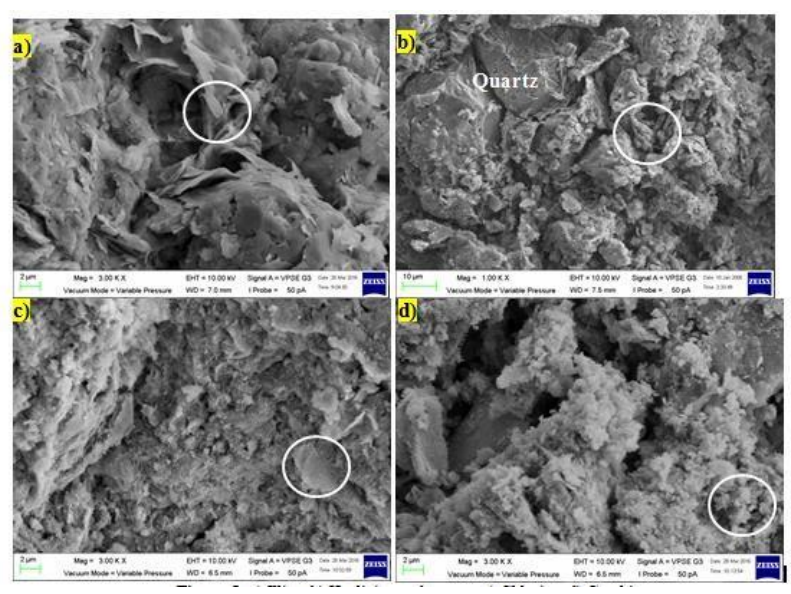

Figure 8: a) Illite; b) Kaolinite and quartz; c) Chlorite; d) Goethite.

Based on this analysis carried out, the Crocker Formation (K1) sample that showed the lowest strength decrement was found to be rich with illite, kaolinite and quartz minerals. Illite minerals with the chemistry of [KAl3Si3O 10 $(\mathrm{OH})_{2}$ ] forms during the hydrolysis of primary mineral such as orthoclase ( $\mathrm{K}$ - feldspar) in the sandstone from Crocker Formation [18]. The kaolinite mineral is also a product of feldspar weathering but it has a different chemistry which is $\left[\mathrm{Al}_{2} \mathrm{Si}_{2} \mathrm{O}_{5}(\mathrm{OH})_{4}\right]$. These minerals basically reduce the strength of the soil due to its weak structure that absorbs moisture. However, the presence of quartz minerals acts as a stabilizer to prevent soil strength reduction. This is because of the characteristics shown by quartz minerals that are very resistant to weathering and increase the soil shear strength.

While, ultrabasic soil sample (K2) was rich with chlorite and goethite which showed a highest strength decrease. Chlorite minerals are secondary minerals that formed during the serpentinization process of ultrabasic rocks. This process involves hydrothermal reactions that changes from primary mineral such as Ca-amphibole (calcite amphibole) to chlorite clay mineral [19]. On the other hand, goethite minerals with the chemistry of $\left[\mathrm{Fe}_{2} \mathrm{O}_{3}\right]$ are categorized as oxides which are commonly reddish-brown in colour and have sharp edges on its surface. The relationship between soil strength and its microstructural properties can be explained via the theory on each clay mineral group as showed in Figure 9.
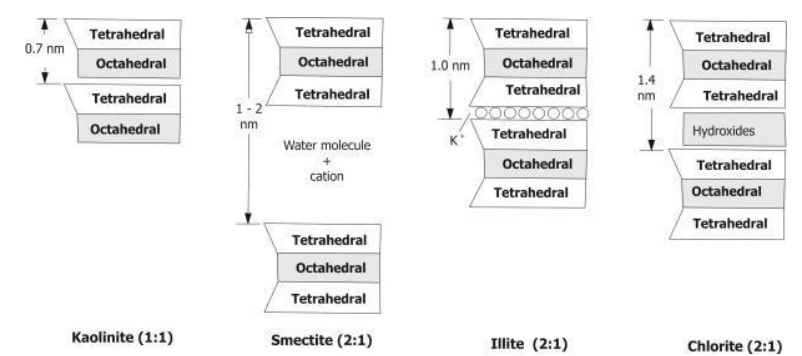

Figure 9: Some structures in the clay mineral group that influences the soil strength (modified fromLory [20]).

Each of the clay mineral group shown has the potential to swell-shrink under various moisture conditions but at different rates. This rate is highly dependent on the arrangement of mineral layers such as 1:1 (kaolinite) and 2.1 (montmorilonite/smectite, illite and chlorite). The 1:1 clay type shows the ratio of one silica tetrahedron layer and one aluminum octahedron layer. On the other hand, the clay type 2:1 is the ratio of two tetrahedron layers and one octahedron layer [20]. These arrangements are vital to facilitate the moisture absorption in a clayey soil like the ultrabasic types. According to Braja (2011), the 1:1 clay type has a much lower distance gap between layers $(0.7$ $\mathrm{nm})$ compared to the 2:1 type which is more than $1 \mathrm{~nm}$. Hence, it can be concluded that a higher presence of the 2:1 clay type in ultrabasic soil samples (K2 and K5) provides a larger distance gap that allows a greater moisture absorption and strength decrement as proven by the laboratory results obtained.

Besides that, the greater strength loss in the K2 ultrabasic sample has some relation with the presence of goethite minerals $[\mathrm{FeO}(\mathrm{OH})]$ in its microstructure. This mineral has a unique potential of adsorption and absorption rate [15] together with the aid of chlorite minerals that causes the soil strength decrement. In order to understand the influence of goethite in this issue, a simple comparison will be made between this mineral from the $\mathrm{K} 2$ sample with the illite mineral from K1 sample. Firstly is the correlation between total specific area of these minerals with its rate of expansion or swelling. Generally, a greater specific area (illite) has a higher rate of expansion as it is able to absorb more moisture content shown in Table 4.

Table 4: The difference between illite and goethite mineral [21].

\begin{tabular}{|c|c|c|}
\hline Mineral type & $\begin{array}{c}\text { Name of } \\
\text { mineral }\end{array}$ & $\begin{array}{c}\text { Total specific } \\
\text { area }\left(\mathbf{m}^{\mathbf{2}} \mathbf{g}\right)\end{array}$ \\
\hline Clay & Illite & $50-200$ \\
\hline Oxide & Goethite & 32 \\
\hline
\end{tabular}

However, illite minerals have been categorized as a nonpresence of non-expandable clay due to the presence of strong bonding between its layers that eventually reduces the rate of water absorption into the illite structures [22]. While, goethite minerals with a lower specific area has a lower tendency of moisture absorption and it is weakly charged. Nevertheless, the unique goethite mineral has an effective adsorption characteristic even though its total specific area is much lower than their counterparts. According to [21], the goethite minerals adsorb water molecules with aid of hydrogen bonding. These bonding are very strong and 
unbreakable which promotes an increase of the rate of adsorption on the goethite mineral surface.

The high presences of goethite are able to adsorb a greater amount of water when there is an increase of manipulated moisture content in the sample. The over adsorption of water molecules can causes the reduction of friction between goethite layers, thus reducing the cohesiveness and the shear strength of soil samples such as K2.

The manipulation of moisture content by increasing it to $3 \%$ or $1 \%$ from its optimum will exhibit various failure behaviors such as the ductile, brittle or intermediate during the soil failure condition. From the results obtained Table 3 previously, most of the samples changes from an intermediate failure condition to plastic type once oversaturation of soil sample occurred. Oversaturated soil is also known as a sample that has a moisture content which exceeded its optimum value. Theoretically, water in the soil influences the pore water pressure between soil particles till a certain limit ( Braja, 2010). Once this limit is exceeded which is in the case of an oversaturated soil samples, then this pore water pressure decreases causing soil to fail in a plastic behavior. Plastic behavior shows a decrease in height and bulging condition of the soil samples (Figure 10). Thus, this failure exhibits a very soft soil consistency because all the samples are in the range of $0-25 \mathrm{kN} / \mathrm{m} 2$ based on [23].

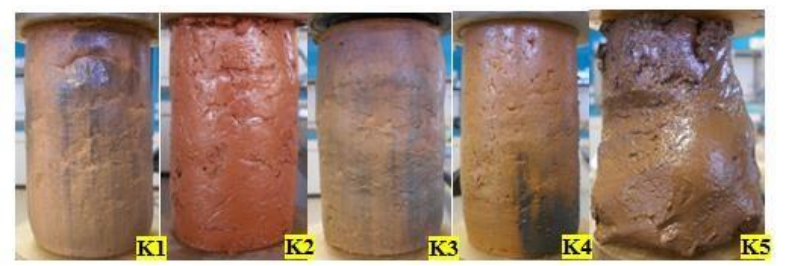

Figure 10: Plastic failure condition exhibited by the tested manipulated moisture content soil samples.

Clay consistency in this analysis represents the degree of cohesive soil solidification. The main factor that influences this consistency is the soil moisture content. A softer consistency degree was shown by all the soil samples when additional moisture content was added into the soil samples. This shows that this type of clay consistency will cause slope failures to occur as drainage of water out of soil sample is extremely slow. Hence, these results obtained in this study were able to analyses the effects of moisture content on soil samples originated from Crocker Formation and ultrabasic type. This can be considered as a general classification of soil strength which can be further experimented and discussed based on its angle of friction, consolidation or even confinement.

\section{CONCLUSION}

A total of 5 samples were tested in this study which are Crocker Formation (K1 \& K3) and ultrabasic (K2, K4 \& K5) soil from various localities around Kampung Lohan, Ranau, Sabah. These samples were suitable to be tested due to its weathering grade of 6 that shows its completely weathered. The tests carried out were particle size distributions (PSD), Scanning Electron Microscope (SEM), Proctor's Compaction and Unconfined Compression Test (UCT). Firstly, PSD results showed that the soil sample of K1 is sandy clay with silt, clay (K2 \& K4) and sandy and silty clay (K3 \& K5) respectively. Then, the relationship between microstructural (SEM) and engineering (UCT) analyses were explained via the usage of 'Decrement Difference of Unconfined Compress ion Strength' formula based on [4]. The manipulated moisture content used was $3 \%$ and $1 \&$ for Crocker Formation and ultrabasic from the optimum moisture content of soil samples respectively. Test of UCT on both optimum and manipulated moisture contents were carried to observe the effect of moisture on the soil strengths. As a result, all samples showed decrement of soil strength about $50.32 \%$ to $90.18 \%$ from the optimum to manipulated value of moisture content in soils. This declining trend of soil strength was also influenced by the microstructural characteristic of the soil. From the SEM analysis, it was observed that the higher presence of swelling minerals like chlorite in the ultrabasic soil samples causes attenuation of soil shear strength during UCT test. While, non-expandable minerals such as illite and kaolinite in the Crocker Formation soil samples showed lowest strength decrement as the minerals has a lower tendency to absorb or adsorb water. It can be summarized that the increasing moisture content in a soil sample will cause reduction in soil cohesiveness and acts a failure agent for soil failure. Thus, soil strength is highly dependent on its moisture content and its microstructural characteristics. Oversaturated soils during the rainy seasons of Malaysia will causes reduction in soil strength due to its declining cohesiveness will eventually trigger soil failure such as landslides and debris flow.

\section{ACKNOWLEDGEMENTS}

The author acknowledges numerous lecturers in the civil, geology and geotechnical fraternity from Universiti Malaysia Sabah (UMS) and Universiti Teknologi Malaysia (UTM) for their constructive comments on this study. Special thanks to UMS for providing logistic support and permitting publication of this article. Finally, Mr. Mohamed Ali Yusof bin Mohd. Husin must be thanked for his unstinting support throughout the execution of the study.

\section{REFERENCES}

[1] Tan, N. K. \& Lamy, J. M. 1990. Tectonic Evolution of the NW Sabah Continental Margin since Late Eocene. Geol. Society of Malaysian Bulletin, 27: 241 - 260.

[2] Tongkul, F. 2017. Active Tectonics in Sabah Sesimicity and Active Faults. Bulletin of Geological Society of Malaysia, 64:27 - 36 .

[3] Bujang, B. K. H., Faisal, H. A., Baker, H. D., Harwant, S., and Husaini, O. 2008. Landslides in Malaysia: Occurrences, Assessment, Analyses and Remediation. Universiti Putra Malaysia Publisher.

[4] Mohamed Ali Yusof bin Mohd Husin and Baba Musta. 2011. Effects of Moisture and Clay 
Microstructure on the Strength of Soil along Kota Belud-Ranau road, Tamparuli, Sabah.

[5] Tija, H. D. 1987. Geomorfologi. Dewan Bahasa dan Pustaka, Kuala Lumpur.

[6] Tjia, H.D., 2007. Kundasang (Sabah) at the Intersection of Regional Fault Zones of Quaternary Age. Geological Society of Malaysia Bulletin, 53, 5966.

[7] Sleep, N. H., Meibom, A., Fridriksson, T., Coleman, R. G., and Bird, D. K. 2004. H2-rich fluids from serpentinization: Geochemical and Biotic Implications. Proceedings of the National Academy of Sciences of the United States of America, 101 (35): 14373 - 14705.

[8] Sanudin Hj. Tahir \& Baba Musta. 2007. Pengenalan kepada Stratigrafi. Universiti Malaysia Sabah Publisher: Kota Kinabalu.

[9] František Mikšík, Štěpánka Freithová, Josef Kotlík, Jiř́ Kučeř́k, Alasdair MacLeod. 2019. The stability of water molecular bridges in ombrotrophic peatland soil. Proceeding of International Exchange and Innovation Conference on Engineering \& Sciences (IEICES), 5, 2019.

[10] British Standard BS 1377. 1990. Methods of Test for Soils for Civil Engineering Purposes. British Standard Institution,London.

[11] Braja, M. D. 2010. Principles of Geotechnical Engineering. Cengage Learning, USA

[12] Head, K. H. 1982, a. Manual of Soil Laboratory Testing Vol. 1: Soil Classification and Compaction Test. Pantech Press. London, Plymouth.

[13] Sahibin, A. R., Wan, M. R. I., Zulfahmi, A. R., Tukimat, L., and Nurul, N. A. S. 2012. PhysicoChemical Properties of Ultrabasic Soil from Petaseh, Negeri Sembilan. National Geoscience Conference Proceeding.

[14] Zulfahmi, A. R., Jasni Yaakob, Sahibin, A. R., Mohd Talib Latip \& Fong Nai Chai. 2006. Sifat Fiziko-Kimia Tanah Potongan Cerun di Sekitar Puchong, Selangor. The Malaysian Journal of Analytical Sciences, Vol 10: 225-232.

[15] Relebohile Mokete, Osama Eljamal. 2019. Analogy of iron-copper and iron-silver bimetals during the corrosion process. Proceeding of International Exchange and Innovation Conference on Engineering \& Sciences (IEICES) 5 (2019).

[16] Alvarado, J. M. 2011. Soil Mechanics Engineering: The Effect of Moisture Content on Soil Strength. California State Science Fair.

[17] Guggenheim, S. 2003. Introduction to the Properties of Clay Minerals. University of Illinois, Chicago.

[18] Tan, K. H. 2009. Environmental Soil Science. 3rd Ed. CRC Press, USA.

[19] Abdel-Rahman, A. M. 1991. Chlorites in a Spectrum of Igneous Rocks: Mineral Chemistry and Para genesis. Mineralogical Magazine of Mineralogical Society, Vol.59: 129-141.

[20] Lory, J. 2015. The Science of Clay related Subsidence. Geological Soil Suvey USA.

[21] Gast, R. G. 1974. Clays and Clay Minerals. The Clay Minerals Society 22:1-22.

[22] Nelson, J. D., Chieh Chao Kuo, Chao, G. K., Overton, D. D., and Nelson, J. E. 2015.
Foundation Engineering for Expansive Soils. John Wiley \& Sons, USA.

[23] Terzaghi, K., Peck, R. B., and Mesri, G. 1996. Soil Mechanics in Engineering Practise. Ed. 3. John Wiley and Sons Inc., USA. 